Research Paper

\title{
Utilization of molasses and sugar cane bagasse for production of fungal invertase in solid state fermentation using Aspergillus niger GH1
}

\author{
F. Veana ${ }^{1}$, J.L. Martínez-Hernández ${ }^{1}$, C.N. Aguilar ${ }^{1}$, R. Rodríguez-Herrera ${ }^{1}$, \\ G. Michelena ${ }^{2}$ \\ ${ }^{1}$ Food Research Department, School of Chemistry, Graduate Program in Food Science and Technology, \\ Universidad Autónoma de Coahuila, Saltillo, Coahuila, México. \\ ${ }^{2}$ Instituto Cubano de Investigaciones de los Derivados de la Caña de Azúcar, Ciudad de La Habana, Cuba.
}

Submitted: April 13, 2012; Approved: September 9, 2013.

\begin{abstract}
Agro-industrial wastes have been used as substrate-support in solid state fermentation for enzyme production. Molasses and sugarcane bagasse are by-products of sugar industry and can be employed as substrates for invertase production. Invertase is an important enzyme for sweeteners development. In this study, a xerophilic fungus Aspergillus niger GH1 isolated of the Mexican semi-desert, previously reported as an invertase over-producer strain was used. Molasses from Mexico and Cuba were chemically analyzed (total and reducer sugars, nitrogen and phosphorous contents); the last one was selected based on chemical composition. Fermentations were performed using virgin and hydrolyzate bagasse (treatment with concentrated sulfuric acid). Results indicated that, the enzymatic yield $(5231 \mathrm{U} / \mathrm{L})$ is higher than those reported by other $A$. niger strains under solid state fermentation, using hydrolyzate bagasse. The acid hydrolysis promotes availability of fermentable sugars. In addition, maximum invertase activity was detected at $24 \mathrm{~h}$ using low substrate concentration, which may reduce production costs. This study presents an alternative method for invertase production using a xerophilic fungus isolated from Mexican semi-desert and inexpensive substrates (molasses and sugarcane bagasse).
\end{abstract}

Key words: by-products, virgin and hydrolyzated bagasse, $\beta$-fructofuranosidase, xerophilic.

\section{Introduction}

Invertase or $\beta$-fructofuranosidase (EC 3.2.1.26) catalyzes the hydrolysis of sucrose into glucose and fructose, acting on non-reducing fructofuranoside terminal residues of $\beta$-fructofuranosides. This enzyme is very important in food industry especially as a catalytic agent to obtain an artificial sweetener (Ashokkumar et al., 2001). In addition, this enzyme has fructosyltransferase activity, which is important for synthesis of short-chain fructo-oligosaccharide compounds. This fact improves intestinal microflora and may prevents cardiovascular disease, colon cancer and osteoporosis (Linde et al., 2009).

For years, production and kinetics of invertase enzyme have been studied using solid state fermentation (SSF) (Aguilar et al., 2008; Aranda et al., 2006), and/or submerged fermentation (SmF) (Ashokkumar et al., 2001, Robledo-Olivo et al., 2009), these studies have revealed higher enzyme production in SSF (Aguilar et al., 2008). Since 1917, Aspergillus niger has become a model organism for solid-state biotechnology. This microorganism is capable of producing enzymes with industrial application, including invertase (Hölker et al., 2004).

Actually, great amounts of agroindustrial wastes are used for enzymes production with industrial interest using SSF (Aguilar et al., 2008). Molasses and sugarcane bagasse are some by-products generated from sugar industry and these can be harnessed and converted with high valorization. Molasses is a viscous and dark liquid, final effluent obtained during the preparation of sugar by repeated crystallization (Leeson and Summers, 2000; Olbrich, 2006). Molasses chemical composition is very varied; where, su-

Send correspondence to G. Michelena. Instituto Cubano de Investigaciones de los Derivados de la Caña de Azúcar, Vía Blanca \#804 y Carretera Central, Zona Postal 10, 11000 San Miguel del Padrón, Ciudad de La Habana, Cuba. E-mail: georgina.michelena@icidca.edu.cu. 
crose (60-63\%), reducing sugars (3-5\%) and trace minerals are the principal compounds (Tellez, 2004; Yepez, 1995). On the other hand, sugarcane bagasse is a residue that remains after sugarcane milling, which is realized for juice extraction (Basanta et al., 2007). These by-products have been employed for animal feed, baking, fuel, paper and cardboard procurement and ethanol, lactic acid, citric acid, sorbitol productions, among others (Atiyeh and Duvnjak, 2003; Basanta et al., 2007). In addition, sugarcane bagasse has been employed as good enzyme inducer, i.e., $\beta$-glucosidase, cellulose, xylanase, tannase, inulinase and invertase (Echegaray et al., 2000; Fouad et al., 2005; Linde et al., 2009; Mazzuti et al., 2006; Olbrich, 2006; Tellez, 2004). However, to our knowledge, there are few reports about use of molasses and sugarcane bagasse for invertase production in SSF.

Based on these antecedents, the present study was carried out with the objective to utilize molasses and sugarcane bagasse for fungal invertase production, employing the invertase over-producer $A$. niger GH1 strain. The strain was isolated from rich-tannin plants from the Mexican semi-desert (Cruz-Hernández et al., 2005) and has been reported as a good invertase producer (Veana et al., 2011).

\section{Materials and Methods}

\section{Microorganism and propagation conditions}

A. niger GH1 (DIA/UAdeC collection) was grown on potato dextrose agar at $30{ }^{\circ} \mathrm{C}$ for 4 days. The fungal spores were harvested with $0.1 \%$ of sterile Tween 80 . The inoculum amount ( $1 \times 10^{7}$ spores/g bagasse) was determined using a Neubauer chamber.

\section{By-products preparation}

Two samples of sugarcane molasses were evaluated: one commercially purchased molasses in México (unknown origin) and molasses proportionated for ICIDCA, La Habana, Cuba (Sugar Enterprise Uruguay, zafra 20092010). Sugarcane molasses were characterized through total and reducer sugar contents using the Lane-Eynon technique, nitrogen content was determined using Kjendhal technique and phosphorous content employing the ammonium metavanadate technique according to ICIDCA procedures for molasses (ICIDCA, 2009). Once, molasses composition was determined, the best molasses was selected and a nutrients balance was realized according to modified Czpek-Dox culture medium, with the following composition (g/L): $\mathrm{NaNO}_{3}$ (7.65); $\mathrm{KH}_{2} \mathrm{PO}_{4}$ (3.04); $\mathrm{MgSO}_{4} 7 \mathrm{H}_{2} \mathrm{O}$ (1.52); $\mathrm{KCl}$ (1.52); and sucrose at $25 \mathrm{~g} / \mathrm{L}$, supplied by molasses sugarcane.

Prior to fermentation, the sugarcane bagasse was subjected to acid hydrolysis with concentrated sulfuric acid for $1 \mathrm{~h}$ boiling, in order to have greater availability of fiber and act as support in SSF. The bagasse (5 g) was placed in Erlenmeyer flasks (1 L), which were employed as reactors.
Therefore, two fermentation systems were development, one with virgin bagasse (VB) and other with hydrolyzated bagasse (HB) which was autoclaved at $121^{\circ} \mathrm{C}$ for $15 \mathrm{~min}$. Finally, molasses was added to both systems according nutrients balance realized previously.

\section{Solid State Fermentation}

The flasks were inoculated with $1 \times 10^{7}$ spores/g bagasse and humidity at $70 \%$. The reactors were incubated at $30{ }^{\circ} \mathrm{C}$. The kinetic was monitored every $24 \mathrm{~h}$ for $72 \mathrm{~h}$. The enzymatic extracts were recuperated: $50 \mathrm{~mL}$ of water were added to flask and were filtered through filter paper. The enzymatic extracts were centrifuged at $1000 \mathrm{rpm}$ for $15 \mathrm{~min}$ and filtered. The filtered was employed for enzymatic activity, sugars consumption and indirect real protein using the methodology described above.

\section{Enzymatic extract characterization}

The invertase activity was determined by measuring the amount of reducing sugars released during the sucrose hydrolysis, using dinitrosalicylic acid reagent (Ashokkumar et al., 2001). One unit of invertase (U) was defined as the amount of enzyme required to liberate $1 \mu \mathrm{mol}$ equivalent of reducing sugars per minute.

Sugars were determined by Lane-Eynon (ICIDCA, 2009) technique with the aim of observing substrate consumption by $A$. niger $G H 1$ in the SSF. The substrate consumption was expressed in percentage; $25 \mathrm{~g} / \mathrm{L}$ of sucrose was considered $100 \%$ of substrate.

The indirect real protein was determinate by Kjendhal technique (ICIDCA, 2009) with a previous treatment of bagasse; $1 \mathrm{~g}$ of bagasse was boiled in $70 \mathrm{~mL}$ of water and copper sulfate $(25 \mathrm{~mL})$ and sodium hydroxide $(25 \mathrm{~mL})$. The solution was cooled and filtered; bagasse washes with water were done in order to eliminate copper through the potassium ferrocyanide addition with a color change of filtered from purple to yellow-transparent. We performed a calibration curve with a standard biomass of $A$. niger Aa20 (0-60 $\mu \mathrm{g})$ for the determination of protein biomass of $A$. niger $\mathrm{GH} 1$ and absorbance at $595 \mathrm{~nm}$ was read; equation of the line was employed for protein obtention. The indirect protein was expressed in percentage ( $\mathrm{g}$ of protein/ $100 \mathrm{~g}$ of fermented bagasse). In addition, invertase specific activity was estimated.

\section{Statistical analysis}

A completely randomized design was proposed for molasses analysis. All results were analyzed using the general lineal procedure and comparison of means by Tukey test using SAS software. The kinetic graphics of invertase activity were plotted in Excel program of Microsoft 2010; standard deviations were added. 


\section{Results and Discussion}

Although the chemical composition of molasses was variable; according to Table 1 not statistical differences for total sugars and phosphorous contents were observed. However, Cuban molasses (Sugar Entreprise Uruguay, 2009-2010 harvest) was selected for SSF because free reducing sugars and phosphorous contents are within reference value (10-15 and 0.1-0.15\%, respectively) (ICIDCA, 2009). In addition, slightly higher nitrogen content is presented.

The maximum invertase activity $(5232 \mathrm{U} / \mathrm{L})$ was observed using HB (Figure 1). This can be attributed to acid hydrolysis, besides; high temperatures promote availability of fermentable sugars by lignocellulosic compounds hydrolysis (Fouad et al., 2005), so bagasse becomes easily susceptible to the microorganisms attack and ultimately the enzymatic production rate increases (Javed et al., 2007). Results in the present study are attributing to all these events.

Other authors have studied invertase production by Aspergillus niger strains. Romero-Gómez et al. (2000) evaluated the invertase production in SmF and SSF (employing polyurethane foam as support) with high sucrose concentration $(100 \mathrm{~g} / \mathrm{L})$ using $A$. niger $\mathrm{C} 28 \mathrm{~B} 25$, A. niger $\mathrm{N}-402$ and $A$. niger Aa20 strains. They demonstrated that using SSF system higher yield enzymatic rate in minor time are obtained, in comparison to SmF. In addition, the best enzyme producing strain was $A$. niger C28B25 (4488 U/L), followed by A. niger Aa20 (3411U/L) and A. niger N-402 (3089 U/L) in 36 and $48 \mathrm{~h}$, respectively.

Asshokumar et al. (2001) employed sugarcane bagasse as support for invertase production by A. niger NRRL 330 with $50 \mathrm{~g} / \mathrm{L}$ of sucrose, using SSF. The authors obtained $5890 \mathrm{U} / \mathrm{L}$ at $72 \mathrm{~h}$ of fermentation; this value is similar to that obtained in the present study $(5232 \mathrm{U} / \mathrm{L})$, however we detected this value at $24 \mathrm{~h}$. This fact is important in industry in order to saving production cost. These also apply for lower substrate concentration (total sugars molasses concentration: $25 \mathrm{~g} / \mathrm{L}$ ).

Similarly, Rubio and Navarro (2006) obtained minor enzymatic yield (3000 and $4000 \mathrm{U} / \mathrm{l})$ comparing with our results, they used sucrose $(10 \mathrm{~g} / \mathrm{L})$ and glucose $(5$ and $10 \mathrm{~g} / \mathrm{L}$ ) in $48 \mathrm{~h}$ culture, not catabolic repression by glucose was observed.

The results obtained in this study are consistent with previous reports, the fact that invertase activity produced

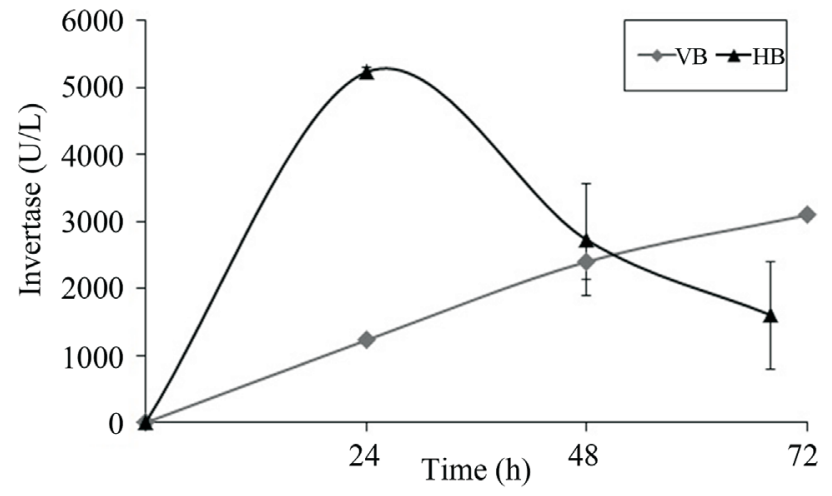

Figure 1 - Invertase activity detected during SSF using A. niger GH1. Sample of HB was monitored only for $68 \mathrm{~h}$ in SSF.

under $\mathrm{SmF}$ is lower than that produced in SSF (Aguilar et al. 2008). Aranda et al. (2006) obtained invertase using $A$. niger Aa20 in SSF. These authors employed sucrose $(25 \mathrm{~g} / \mathrm{L})$ and different glucose concentrations. The maximum activity of $212 \mathrm{U} / \mathrm{L}$ was obtained in glucose $100 \mathrm{~g} / \mathrm{L}$ and in medium only with the inducer, $140 \mathrm{U} / \mathrm{L}$ were detected. In terms of productivity, in the present study we increased 30 times productivity than other authors using different A. niger strains in SmF and SSF (Aranda et al., 2006; Ashokkumar et al., 2001; Paranthaman et al., 2008; Robledo-Olivo et al., 2009; Rubio and Maldonado, 1995).

The substrate was consumed for A. niger GH1, according different needs and adaptation to SSF (Figure 2). At $24 \mathrm{~h}, 90 \%$ of substrate was consumed, time where the maximum invertase activity was detected in SSF with VB; at $48 \mathrm{~h}$ substrate was exhausted in two fermentation systems. While in SSF employing HB, a decrease in activity in the next hours was observed, which is due to insufficient substrate availability. Probably, A. niger GH1 begin the proteases secretion to culture medium, which degraded protein and reduced the culture yield.

Robledo-Olivo et al. (2009) reported that the maximum invertase activity of $3873 \mathrm{U} / \mathrm{L}$ was obtained with $12.5 \mathrm{~g} / \mathrm{L}$ of sucrose followed by $25 \mathrm{~g} / \mathrm{L}$ of sucrose, which recorded $2585 \mathrm{U} / \mathrm{L}$ but there was no significant difference between 12.5 and $25 \mathrm{~g} / \mathrm{L}$ of substrate. So, in the present study is correct the employment of $25 \mathrm{~g} / \mathrm{L}$ of total sugars of molasses and comparing the invertase activity, the results are higher than those reported previously by different authors using other A. niger strains (Ashokkumar et al., 2001; Romero-Gómez et al., 2000). The maximum indirect pro-

Table 1 - Chemical characterization of two molasses from different origin.

\begin{tabular}{lcccc}
\hline Molasses & Total sugars (\%) & Free reducing sugars (\%) & Nitrogen (\%) & Phosphorous (\%) \\
\hline Mexico & $51.63 \pm 1.56^{\mathrm{a}}$ & $18.15 \pm 0.30^{\mathrm{b}}$ & $0.28 \pm 0.05^{\mathrm{a}}$ & $0.17 \pm 0.01^{\mathrm{a}}$ \\
Cuba & $50.58 \pm 0.86^{\mathrm{a}}$ & $12.31 \pm 1.11^{\mathrm{a}}$ & $0.43 \pm 0.01^{\mathrm{b}}$ & $0.14 \pm 0.02^{\mathrm{a}}$ \\
\hline
\end{tabular}

Note: Means with same letter, in the same column, are not significantly different according Tukey test ( $\alpha=0.05,95 \%$ probability). 


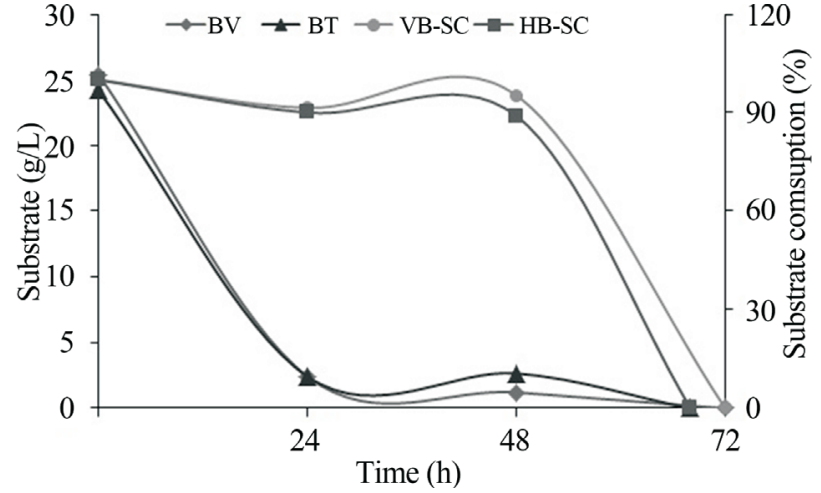

Figure 2 - Percentage of substrate consumption by $A$. niger GH1 during $\mathrm{SSF}$ with initial concentration of sucrose (molasses) at $25 \mathrm{~g} / \mathrm{L}$. Sample of $\mathrm{HB}$ was monitored only for $68 \mathrm{~h}$ in SSF.

tein $(1 \%)$ detected during SSF was present at $72 \mathrm{~h}$ (Figure 3) with VB and $0.87 \%$ at $68 \mathrm{~h}$ with $\mathrm{HB}$, however this behavior is very different in specific activity, because there is not relationship between protein-invertase production. Specific activity is a parameter that indicates enzyme purity, if this value is high, indicates that of total protein content the main amount is invertase. $390 \mathrm{U} / \mathrm{mg}$ protein in crude extract during SSF at $24 \mathrm{~h}$ from $A$. niger GH1 was detected (Figure 3 ). Activity specific has been reported from crude extracts and with purification steps in previous studies and the obtained values has been lower than those reported in the present investigation. Boddy et al. (1993) obtained a specific activity of $143 \mathrm{U} / \mathrm{mg}$ protein in crude extract from $A$. niger B60. Different values were found by Rubio and Maldonado (1995), with a specific activity of $11.11 \mathrm{U} / \mathrm{mg}$ of protein in crude extract and $96 \mathrm{U} / \mathrm{mg}$ of protein after purification steps. Similarly, Nguyen et al. (2005) obtained $1.04 \mathrm{U} / \mathrm{mg}$ of protein in crude extract and 51.67 $\mathrm{U} / \mathrm{mg}$ of protein in purified extract from $A$. niger

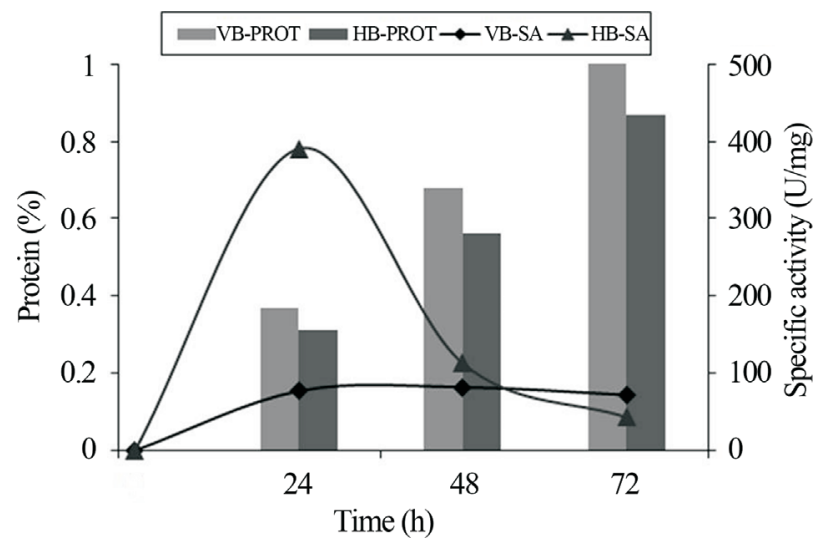

Figure 3 - Indirect proteins (g of protein/ $100 \mathrm{~g}$ of fermented bagasse) and specific activity detected during SSF using $A$. niger GH1. Sample of HB was monitored only for $68 \mathrm{~h}$ in SSF. VB-PROT and HB-PROT: virgin bagasse and hydrolysate bagasse proteins, respectively; VB-SA and HB-SA: specific activities of virgin and hydrolysate bagasse, respectively.
IMI303386. Then, Vargas et al. (2004) obtained 5.18 and $5.38 \mathrm{U} / \mathrm{mg}$ of protein of $A$. niger

CCT7415 cultivated in molasses medium with 8 min of sonication and amplitude of 20 and 40, respectively. Later, Novaki et al. (2010) obtained $342 \mathrm{U} / \mathrm{mg}$ of protein by SSF of soybean bran using Aspergillus casiellus. Comparing our results with those obtained by other authors, we observed that $A$. niger $\mathrm{GH} 1$ is a good alternative for invertase production in SSF using bagasse and sugarcane molasses. Specific activity detected in crude extract is high, so probably when this enzyme will be purified, purification steps will be less, therefore, the process will be cheaper.

\section{Conclusions}

In the present study, the ability of the A. niger GH1 fungal strain for invertase production in less time under SSF, employing as substrates and support in SSF byproducts (molasses and sugar cane bagasse) of sugar industry demonstrated. The enzyme industry can be beneficiate employing this by-products and $A$. niger GH1 fungal strain for invertase production, due to low enzyme production costs.

\section{Acknowledgments}

F. Veana wants to thank to CONACYT (National Council of Science and Technology of Mexico) for the financial support and to ICIDCA for the technical support during the research visit in this institution.

\section{References}

Aguilar CN, Gutiérrez-Sánchez G, Prado-Barragán LA, Rodríguez-Herrera R, Martínez-Hernández JL, ContrerasEsquivel JC (2008) Perspectives of solid state fermentation for production of food enzymes. Am J Biochem Biotechnol 4:354-366.

Aranda C, Robledo O, Loera O, Contreras-Esquivel JC, Rodríguez HR, Aguilar CN (2006) Fungal invertase expression in solid-state fermentation. Food Technol Biotechnol 44:229-233.

Ashokkumar B, Nagarajan K, Paramasamy G (2001) Optimization of media for $\beta$-fructofuranosidase production by Aspergillus niger in submerged and solid state fermentation. Process Biochem 37:331-338.

Atiyeh H, Duvnjak Z (2003) Production of fructose and ethanol from cane molasses using Saccharomyces cerevisiae ATCC 36858. Acta Biotechnol 23:37-48.

Basanta R, García-Delgado MA, Cervantes-Martínez JE, MataVázquez H, Bustos-Vázquez G (2007) Sustainable recycling of waste from sugarcane agroindustry: A review. Cienc Tecnol Aliment 5:293-305.

Boddy LM, Bergés T, Barreau C, Vainstein MH, Dobson MJ, Balance DJ, Peberdy JF (1993) Purification and characterisation of an Aspergillus niger invertase and its DNA sequence. Curr Genet 24:60-66.

Cruz-Hernández MA, Contreras-Esquivel JC, Lara F, Rodríguez HR, Aguilar CN (2005) Isolation and evaluation of tan- 
nin-degrading fungal strains from the Mexican Desert. Z Naturforsch C 60:844-848.

Echegaray OF, Carvalho JCM, Fernandes ANR, Sato S, Aquarone E, Vitolo M (2000) Fed-batch culture of Sacchoromyces cerevisiae in sugar-cane blackstrap molasses: invertase activity of intact cells in ethanol fermentation. Biomass Bioenergy 19:39-50.

Fouad SB, Jover J, González E (2005) A study of single-step hydrolysis of bagasse with concentrated sulphuric for obtaining ethanol and in a modified single step and corresponding technical-economic analysis. Ing Investig 25:34-38.

Hölker H, Höfer M, Lenz J (2004) Biotechnological advantages of laboratory-scale solid-state fermentation with fungi. Appl Microbiol Biotechnol 64:175-186.

ICIDCA (2009). Manual de Técnicas analíticas del ICIDCA. Editorial Pueblo y Educación, La Habana, Cuba.

Javed MM, Khan TS, Ul-Haq I (2007) Sugar cane bagasse pretreatment: an attempt to enhance the production potential of cellulose by Humicola insolens TAS-13. Electro J Environ Agric Food Chem 6:2290-2296.

Leeson S, Summers J (2000) Nutrición Aviar Comercial. LePrint Club Express Ltda Bogotá, Colombia.

Linde D, Macías I, Fernández-Arrojo L, Plou FJ, Jiménez A, Fernández-Lobato M (2009) Molecular and biochemical characterization of a $\beta$-fructofuranosidase from Xanthophyllomyces dendrorhous. Appl Environ Microbiol 75:1065-1073.

Mazzuti M, Bender JP, Treichel H, Di Luccio M (2006) Optimization of inulinase production by solid-state fermentation using sugarcane bagasse as substrate. Enzym Microb Technol 39:56-59.

Mohd NNB (2006) Production of xylanase enzyme from Aspergillus niger using sugarcane bagasse; the effect of substrate concentration. Pahang, Malaysia, 22-23 pp. (Bachelor Thesis. Faculty of Chemical and Natural Resources Engineering. UMP).

Nguyen QD, Rezessy-Szabo JM, Bhat MK, Hoschke A (2005) Purification and some properties of $\beta$-fructofuranosidase from Aspergillus niger IMI303386. Process Biochem 40:2461-2466.

Novaki L, Hasan SDM, Kadowaki MK, Andrade D (2010) Produção de invertase por fermentação em estado sólido a partir de farelo de soja. Engevista 12:131-140.
Olbrich H (2006) The molasses. Biotechnologie-Kempe GmbH, Germany.

Paranthaman R, Vidyalakshmi R, Murugesh S, Singaravadivel K (2008) Optimisation of fermentation conditions for production of tannase enzyme by Aspergillus oryzae using sugarcane bagasse and rice straw. Glob J Biotechnol Biochem 3:105-110.

Robledo-Olivo A, Contreras-Esquivel JC, Rodriguez HR, Aguilar $\mathrm{CN}$ (2009) Induction and repression kinetics of fungal beta-fructofuranosidase in submerged culture. Int $\mathrm{J}$ Food Eng 5:1-13.

Romero-Gómez SJ, Augur C, Viniegra-González G (2000) Invertase production by Aspergillus niger in submerged and solid-state fermentation. Biotechnol Lett 22:1255-1258.

Rubio MC, Maldonado MC (1995) Purification and characterization of invertase from Aspergillus niger. Curr Microbiol 31:80-83.

Rubio MC, Navarro AR (2006) Regulation of invertase synthesis in Aspergillus niger. Enzym Microb Technol 39:601-606.

Tellez D (2004) Caracterización de las melazas empleadas en el proceso fermentativo de la destilería San Martín-Industria de Licores del Valle. Santiago de Cali, Colombia. (Barchelor Thesis. Facultad de salud, Escuela de Bacteriología y laboratorio clínico. UV).

Vanderlei NC, Moreira SFH, Chodi MD, Asis LF, Peralta MR, Atílio JJ, Melo FRP (2010) Purification and biochemical properties of a glucose-stimulated $\beta$-D-glucosidase produced by Humicola grisea var. thermoidea grown on sugarcane bagasse. J Microbiol 48:53-62.

Vargas LHM, Pião ACS, Domingos RN, Carmona EC (2004) Ultrasound effect on invertase from Aspergillus niger. World $\mathrm{J}$ Microbiol Biotechnol 20:137-142.

Veana F, Aguilar CN, Rodríguez HR (2011) Kinetic studies of invertase production by xerophilic Aspergillus and Penicillium strains under submerged culture. Micol Apl Int 23:37-45

Yepez Y (1995) Selección de una cepa de Saccharomyces cerevisiae con alta productividad de etanol y que tolere mayores niveles de azúcar que los usados en la Planta Alcoquímica Sucromiles S.A. Bogotá, Colombia. (MSc. Thesis. Facultad de Ciencias. PUJ).

All the content of the journal, except where otherwise noted, is licensed under a Creative Commons License CC BY-NC. 